\title{
Unit Cost Analysis of Sectio Caesarea with Activity-Based Costing in Yogyakarta Hospital
}

\author{
Rijal Maulana Haqim*, Firman Pribadi*
}

* Correspondence Author: rijalmaulanahaqim@gmail.com

* Master of Hospital Management, Universitas Muhammadiyah Yogyakarta, Indonesia

\begin{tabular}{l}
\hline I N D E X I N G \\
\hline Keywords: \\
Unit Cost; \\
Sectio Caesarea; \\
Activity-Based Costing;
\end{tabular}

Kata Kunci:

Biaya Satuan;

Sectio Caesarea;

Activity Based-Costing;

\begin{abstract}
A B S T R A C T
The selection of unit cost calculation method in hospital services is a challenge for hospitals. Errors in the selection of the calculation method will make a big difference in the final results of the total costs required after the service. Yogyakarta City Hospital still uses traditional methods of determining service rates. Design of this study is a qualitative study with a case study approach to the unit costs required for uncomplicated section Caesarea which is calculated using the activity-based costing method compared to the unit cost of section Caesarea calculated using traditional methods. The purposes are to know the differences between the two methods. The results of this study indicate the unit cost of uncomplicated section Caesarea using the ABC method is IDR 2,703,919. the action rate by the hospital is IDR. 3,051,000, greater than the $\mathrm{ABC}$ method. The difference obtained is $\mathrm{Rp}$ 347,081 . The Conclusions is a positive difference between the unit cost of the ABC method and the hospital rate so it is necessary to evaluate the service rates in Yogyakarta City Hospital.
\end{abstract}

Pemilihan metode penghitungan unit cost pelayanan Rumah Sakit menjadi tantangan bagi Rumah Sakit, karena kesalahan dalam pemilihan metode penghitungan akan dapat memunculkan selisih yang besar dalam hasil akhir dari total biaya yang diperlukan setelah pelayanan. RSUD Kota Yogyakarta masih menggunakan metode tradisional dalam menentukan tariff pelayanan. Desain penelitian ini adalah penelitian kualitatif dengan pendekatan studi kasus terhadap biaya satuan / unit cost yang dibutuhkan untuk tindakan sectio caesarea tanpa penyulit yang dihitung menggunakan metode Activity-Based Costing dibandingkan unit cost tindakan sectio caesarea yang dihitung menggunakan metode tradisional. Tujuannya adalah mengetahui selisih diantara kedua metode tersebut. Hasil penelitian ini menunjukkan unit cost tindakan sectio caesarea tanpa penyulit menggunakan metode ABC sebesar Rp 2.703.919,00 Tarif tindakan yang ditetapkan rumah sakit sebesarRp 3.051.000,00 lebih besar dari pada metode ABC. Selisih yang didapatkan adalah sebesar Rp347.081,00. Terdapat selisih positif antara unit cost metode ABC dengan tariff Rumah Sakit sehingga perlu dilakukan evaluasi terhadap tarif pelayanan di RSUD Kota Yogyakarta

(C) 2019 JMMR. All rights reserved Article history: Received 2019-Jan-13; Revised 2019-Jan-14; Accepted 2019-Apr-18

\section{INTRODUCTION}

Indonesia is a country that uses the social security system as a system in its world of health. According to the law of the Republic of Indonesia Number 40 of 2004, social security is a form of social protection to guarantee that all people can fulfill the basic needs of a decent life. Social security is regulated in a system called the National Social Security System. The National Social Security System is a procedure for the implementation of social security programs by several social security implementing agencies (BPJS). ${ }^{-}$The National Social Security System has a target to meet Universal Health Coverage (UHC) in 2019. ${ }^{2}$

Universal health coverage is a situation where everyone can receive health services according to their needs without experiencing difficulties in terms of payment. ${ }^{-}$
Warranty era will make all health services at the first level focus on activities of promotion, prevention, rehabilitation and palliative care. This situation will make hospitals have to move more effectively and efficiently. ${ }^{-}$ Doctors can no longer provide excessive therapy to patients. This will make the costs spent by the hospital going to be greater than the claim cost given by the national health insurance institution. The Hospital plays a major role in determining it business strategy including determining the unit price / unit cost of services. ${ }^{4}$ The more complex and competitive a hospital market, will make the service rates lower. ${ }^{4}$

Sectio Caesarea (SC) is an artificial labor, which the fetus is born through an incision in the abdominal wall and uterine wall provided that the uterus is intact and the fetus weighs above 500 grams. ${ }^{5}$ According to Riskesdas 2013, 
the incidence of sectio caesarea in Indonesia has a figure of 9.8 percent. The cost package of sectio caesarea between hospitals has a high rate of variation. ${ }^{-}$The selection of unit cost calculation method in hospital services is a challenge for it hospitals, because errors in the selection of the calculation method will be able to cause a large difference in the final results of the required total costs after the service.

A study did by ${ }^{7}$ showed a significant difference in the rate of medical action in a hospital in Iran when calculated using the Activity-Based Costing (ABC) method compared to the Traditional Cost System (TCS) method. The ABC method produces a higher price on the action rate. This will be the first step for the hospital to avoid loss of money.

The purpose of this study was to determine the unit cost of Sectio Caesarea in Yogyakarta City Hospital using the Activity-Based Costing method and find out the difference in it using Activity-Based Costing method compared to real cost.

\section{LITERATURE REVIEW}

Sectio caesarea is an artificial labor, in which the fetus is born through an incision in the abdominal wall and uterine wall provided the uterus is intact and the fetus weighs above 500 grams. ${ }^{5}$ Sectio caesarea is an artificial labor in which the fetus is born through an incision in the front wall of the stomach and uterine wall with uterine conditions intact accompanied by certain indications. The risk of sectio caesarean action must be considered and examined, because it can threaten the lives of both the mother and the fetus.

There are two perspectives on indications of sectio caesarea. the first is an indication to the mother: (1) Narrow pelvis. (2) Ruptur uteri. (3) Pre eklampsi / eklampsi. (4) Placenta Previa. The second perspective is seen from the fetus; (a) Severe Fetus, (b) Fetal presentation, (c) Twins, (d) Fetal size.

Costs are cash or assets worth of cash that are issued to obtain services or goods and are expected to be investments that will bring benefits now and / or in the future for an organization. ${ }^{-}$Unit cost is the cost of a unit of goods / services. Service coverage must be determined in advance to be able to calculate a unit cost.

Calculation of unit cost is broadly obtained from Total cost (TC) divided by Number of Products (Q). High and low unit costs can be influenced by the products produced (output) and the amount of costs incurred by the Hospital in order to provide services. ${ }^{-}$The smaller the unit cost is, the more complex the method of calculating unit costs is used. ${ }^{?}$

Cost analysis is a method or action whose purpose is purely for evaluation, carried out entirely without regard to the possibility of using the results of a decision, or as input to a decision. ${ }^{10}$ In this research, Activity-based costing calculation method is used. It is a method of determining production prices by using cost drivers to assess indirect costs needed to produce products / services..$^{11}$

Determining service fees from a hospital is not easy. Hospitals need to choose the right method after compiling and dividing expenditure costs into direct costs and indirect costs. Rates of action that need to be taken at the Hospital include tariffs for surgical services, hospitalization rates per day, rates for visiting doctors, etc. The service tariff is very important determined in the era of prospective payments, ie the service rates are informed in advance before services are provided.

Activity-Based Costing was developed to replace other methods that have weakness. ${ }^{7}$ It uses a cost driver by measuring the activities used in producing an item / service so that indirect costs can be calculated. The ideal cost driver is one that presents all activities carried out in an effort to procure goods / services. $\stackrel{11}{ }$

There are two important elements in Activity-Based Costing,

1. Cost measure

2. Performance measure.

Activities, resources and cost objects are used to measure a cost and performance. $\mathrm{ABC}$ does not deny the relationship between the cost driver for activity. The traditional view of cost accounting is that the product or service will consume resources, while the $\mathrm{ABC}$ 's view of cost accounting is that the product or service will consume activities, then consume resources. $\frac{12}{}$

The basis for calculating costs using the $\mathrm{ABC}$ method is to look at and identify cost drivers or cost triggers for each activity. Errors in seeing and identifying cost drivers can trigger errors in the classification of costs that will have an impact on the decisions taken. The ABC method is a method that takes an approach to developing the amount of costs used in financing. A distinctive feature of $\mathrm{ABC}$ is the focus on activity as a cost object. $\frac{12}{}$

\section{Advantages of $\mathrm{ABC}$}

Activity-based costing is an applicable unit cost calculation method for various hospitals. ${ }^{7}$ One study conducted by $\stackrel{13}{-}$ stated in a Hospital in the City of London, with management experiencing pressure due to the 
economic conditions of the Hospital, using the ActivityBased Costing method as an effective method for the Hospital. Research conducted by $\frac{14}{2}$, shows that the application of the activity-based costing method in the financial system for knee replacement measures can save costs of USD 827.62 each time the operation. Research conducted by $\underline{15}$ regarding unit cost analysis of appendectomy operating procedures with activity based costing methods at PKU Muhammadiyah Hospital in Bantul states that the activity-based costing method has a positive difference compared to real cost which indicates that there are several calculated cost sources well using this method. Another advantage of using activity-based costing in calculating unit costs includes:

1. Activity-based costing can calculate by considering the relationship between cause and effect of a relationship between activities and costs of services. $\frac{16}{}$

2. Activity-based costing also provides actual information from the results of unit cost calculations ${ }^{16}$

3. Activity-based costing focuses on data activities carried out in the process sequence of a product or service $\stackrel{17}{-}$ (AN, 2009).

4. Activity-based costing can potentially improve management resources. $\frac{17}{}$

5. Activity-based costing consequently increases the efficiency of health service organizations by prioritizing the value of customers. $\frac{18}{}$

\section{RESEARCH METHOD}

The research chosen by the author is a qualitative study with a case study approach to the unit cost / unit cost needed for sectio caesarea without complications which is calculated using the Activity-Based Costing method then seen the difference / difference with the sectio caesarea rate of action calculated using the real cost method

This research has been conducted at Yogyakarta City Hospital, the number 1 street in Yogyakarta in October 2018 - December 2018.

The research subjects included the head of the finance department, the head of the Central Surgical Installation, the Gynecologist, Surgical Nurse, the Head of Medical Records, the Head of CSSD (Central Supply Sterile Department) and the maintenance department to obtain comprehensive data at Jogja Hospital. The research's object are all activities that occur in the Central Surgical Installation of Yogyakarta City Hospital for the realization of the caesarea sectio service.

The instruments used in this study:
1. Documentation and financial data of Yogyakarta City Hospital

2. Stop watch.

In collecting data, the author uses interview and observation methods.

This study uses primary and secondary data. Primary data is data obtained directly through interviews. Secondary data is data from existing information, which is the financial data of Yogyakarta City Hospital. The processing of primary data and secondary data is processed into direct and indirect cost data during the operation of cesarean sectio without complications which is the cost allocation of the related units (service, support, and non-medical)

The data analyzed using the activity based costing method and described as follows

1. Determine activity centers in the related unit.andcost driver categories of each cost category.

2. Imposing direct costs for sectio caesarea without complications.

3. Determine direct resource overhead and indirect resource overhead

4. Charges overhead costs in each activity center

5. Add direct and overhead costs

6. Comparing costs using $\mathrm{ABC}$ calculations with the costs set by the Hospital

\section{RESULT AND DISCUSSION}

\section{Hospital Profile}

Yogyakarta City Hospital is government hospital located in Wirosaban street number 1 Yogyakarta. The vision of Yogyakarta City Hospital is The realization of excellent service and the main choice of the community. RSUD Kota Yogyakarta have 6 missions to realize it's vision:

1. Realize the highest standards of service based on patient safety, according to customer needs and expectations;

2. Improve employee competency and performance on an ongoing basis;

3. Realizing Education Hospital, a vehicle for research, training and development;

4. Establishing a reliable Hospital Information and Management System;

5. realize effective and efficient management in an integrated and conducive work climate; 
6. join in realizing Yogyakarta as a city with a healthy environment

\section{Hospital Facility}

1. Emergency Unit

2. Outpatient Unit

Outpatient services in RSUD Kota Yogyakarta include Gynecology and Obstetrics Polyclinic, Internal Medicine Polyclinic, General Surgery Polyclinic, Orthopedic Polyclinic, Urology Polyclinic, Pediatric Polyclinic, Neural Polyclinic, Eye Disease Polyclinic, ENT Polyclinic, Mental Polyclinic, Skin and Gender Polyclinic, Rehabilitation Polyclinic Medical, Heart Polyclinic, Agreement Polyclinic, Medical Check Up Service, Psychology Consultation, Child Immunization, VCT HIV, Nutrition Consultation Service

3. Inpatient Unit

Inpatient services in RSUD City Yogyakarta include the Vinolia Ward (VIP), Class I Ward, Class II Ward, Class III Ward, Perinatal Room, Intensive Care Unit (ICU), Intensive Cardiac Care Unit (ICCU).

4. Maternity Room Services

Maternity Room Services in RSUD Kota Yogyakarta prioritize comfort and privacy for patients who will give birth.

5. Surgery Room

Surgery Room Services in RSUD Kota Yogyakarta provide specialist and subspecialty surgical services with sophisticated equipment. Services available include general surgery, urology surgery, orthopedic surgery, digestive surgery, obsgyn, eye, and oral surgery. There are 4 operating rooms available in the operating room of Yogyakarta Public Hospital.

6. Medical Support Services

Medical support services in RSUD Kota Yogyakarta include 24-hour Laboratory Services, Hemodialysis, X-Ray Radiology Services, CT Scan, MMR, Mammography, Colon in Loop, HSG, Endoscopy, Colposcopy, Audiometry, Spirometry,
Electrocardiography, Ultrasound, Treadmill, BERA, EEG, Laparoscopy

\section{Patient Visit}

The population of the yogyakarta in 2017 amounted to 410,921 with details of 200,425 male, 210,496 women. Patient visit in RSUD Kota Yogyakarta can be seen in the following graph. Total patient visit in Yogyakarta city is 580.709 patient. The details can be seen in table 1 .

Table 1. Patient Visit in Yogyakarta city 2017

\begin{tabular}{lcc}
\hline \multicolumn{1}{c}{ Unit } & Patient & Percentage (\%) \\
\hline Inpatient Unit & 121044 & 21 \\
Outpatient Unit & 9626 & 2 \\
Surgery Room & 3874 & 1 \\
Emergency Unit & 26701 & 5 \\
Medical & 419464 & 72 \\
Support & 580709 & 100 \\
Total & &
\end{tabular}

Surgery unit experienced an increase in the last 5 years

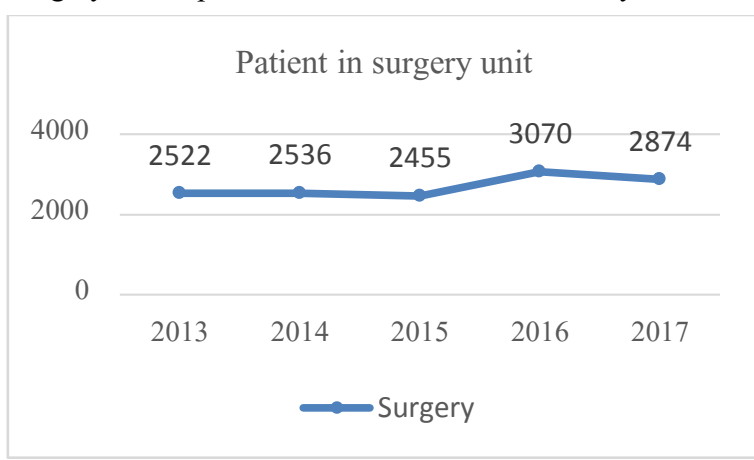

Graph 1. Patient Visit in Yogyakarta city

On graph 1. it can be seen that the number of visits in the operating unit tends to be stable

\section{Result}

\section{Sectio caesarea services}

Sectio caesarea services in Yogyakarta City Hospital were carried out in the operation room of the Central Surgery Installation. Central Surgical Installation Yogyakarta Hospital has four operating room, each operating room is equipped with an operating table, operating lights, air conditioner, caution machine, suction and anesthesia machine.

Surgical measures without complications in the Yogyakarta City Hospital were carried out by a team consisting of 1 obstetrician as an operator, 1 assistant, 1 
assistant instrument, anesthesiologist, anesthetist, and mobile nurse (on loop).

\section{Unit Cost Sectio Caesarea}

Determine activity centers and cost driver

The first step of this research is determine the activity center and cost driver of sectio caesareaAccording to obstretic and gynecologist doctor, there are the activity centers in operation room to realize sectio caesarea services.

Table 2.Activity centers of sectio caesarea

\begin{tabular}{|c|c|}
\hline ACTIVITY CENTER & $\begin{array}{c}\text { COST } \\
\text { DRIVER }\end{array}$ \\
\hline \multicolumn{2}{|l|}{ Operating Room (Preoperative) } \\
\hline $\begin{array}{l}\text { Patient admission by IBS officers from ward } \\
\text { nurses }\end{array}$ & Activity \\
\hline Giving antibiotic profilaksis & Activity \\
\hline $500 \mathrm{cc} \mathrm{NaCl}$ infusion liquid & Activity \\
\hline \multicolumn{2}{|l|}{ Operating Room (operating durante) } \\
\hline Examination of vital signs by the anesthetist & Activity \\
\hline Regional Anesthetic Actions (Spinal) & Activity \\
\hline The action of sectio caesarea & Activity \\
\hline Check for complications and bleeding & Activity \\
\hline \multicolumn{2}{|l|}{ Post Operation Operating Room } \\
\hline Score by anesthetist & Activity \\
\hline Handover of patients by IBS officers to nurses & Activity \\
\hline
\end{tabular}

Determine direct cost

Then followed by direct costs of caesarea sectio without complications, direct costs borne by the patient are the cost of sterilizing equipment, doctor services and consumables.

Table 3. Direct cost of sectio caesarea

\begin{tabular}{lr}
\hline \multicolumn{1}{c}{ Cost Category } & Cost (Rp) \\
\hline Obstetric doctor services & 780,000 \\
Anesthetis doctor services & 260,000 \\
Instrument sterilization & 188,829 \\
Standart set Sectio caesarea & 18,606 \\
Ringer Lactat 500 cc x 4 & 34,320 \\
Threeway & 12,540 \\
Transfusi set & 16,764 \\
Jelco 18 & 10,440 \\
DC no 16 & 18,612 \\
AmbacimInj 1 gr/vial & 118,550 \\
NaCl & 12,097 \\
Urine Bag & 5,148 \\
\hline
\end{tabular}

Table 3. (continued) Direct cost of sectio caesarea

\begin{tabular}{|c|c|}
\hline Cost Category & Cost (Rp) \\
\hline Folamil Tab x 10 & 11,790 \\
\hline Aqua Pro Inj $25 \mathrm{ml} \mathrm{x} 3$ & 10,287 \\
\hline Modres Trans Dressing & 5,346 \\
\hline HS Non Steril Gloves x 19 & 15,960 \\
\hline Spuit10 cc Terumo & 2,400 \\
\hline HandscoonSterilTeruglove x 7 & 53,130 \\
\hline Spinal needle 25 & 38,401 \\
\hline Spuit 5 cc Terumo x 3 & 5,736 \\
\hline Spuit 3 cc Terumo $\mathrm{x} 3$ & 6,534 \\
\hline InfusAsering x 4 & 46,604 \\
\hline AsamTraneksamatInj 100 x 3 & 15,468 \\
\hline OndansetronInj $2 \mathrm{mg} / \mathrm{ml}$ & 1,285 \\
\hline yarn ATR r-VIO & 77,979 \\
\hline Masker disposible x 4 & 1,532 \\
\hline OksitosinInj $10 \mathrm{IU} / \mathrm{ml}$ x 2 & 2,878 \\
\hline Hibice $1 \mathrm{~L} \times 0.03$ & 6,194 \\
\hline Terastarch & 112,200 \\
\hline Hibiscrub $1 \mathrm{~L} \times 0.05$ & 13,068 \\
\hline Folding gauze DRC x 60 & 100,980 \\
\hline HandscoonSterilGamex x 3 & 34,452 \\
\hline $\mathrm{O} 2$ & 20,400 \\
\hline Polifix x 0,02 & 3,116 \\
\hline Regivel & 74,382 \\
\hline Alkohol 70\% $1 \mathrm{~L}$ x 0.01 & 2,401 \\
\hline Povidone Iodine $1 \mathrm{~L}$ x 0.10 & 5,520 \\
\hline Yarn T-plane catgut & 48,520 \\
\hline EfedrinInj $50 \mathrm{mg} / \mathrm{ml} \mathrm{x} 2$ & 20,565 \\
\hline MetilergometrinInj x 2 & 6,838 \\
\hline ElofionInj $30 \mathrm{mg}$ & 33,660 \\
\hline Benang T-cromic Catgut & 60,071 \\
\hline Bisturi FG 23 & 3,348 \\
\hline NaClinfus (Sanbe) & 25,186 \\
\hline Underpad Healer & 3,864 \\
\hline KetorolakInj $30 \mathrm{mg} / \mathrm{ml}$ x 3 & 9,819 \\
\hline Spuit 5 cc OneMed x 5 & 3,145 \\
\hline Sensipad x 3 & 9,966 \\
\hline Spuit 3 cc Terumo x 6 & 13,068 \\
\hline RL $500 \operatorname{cc} \times 4$ & 34,820 \\
\hline Ketoprofen Tab $100 \mathrm{mg}$ & 15,075 \\
\hline TOTAL & $2,437,332$ \\
\hline
\end{tabular}


According to the table 3, direct cost of sectio caesarea is $\mathrm{Rp}$ 2.437.332,00. The biggest cost is allocated in medical doctor services that consumes $43 \%$ from total of direct cost.

The next step is determine overhead costs. Overhead costs consist of indirect resource overhead and direct resource overhead costs

Determine direct resource overhead and indirect resource overhead

Table 4. Indirect resource overhead nonfunctional unit

\begin{tabular}{lr}
\hline \multicolumn{1}{c}{ Cost Category } & \multicolumn{1}{c}{ Cost (Rp) } \\
\hline Labour Related & \\
\hline Laboursalary & $8,134,901,585$ \\
\hline Equipment related & \\
\hline $\begin{array}{l}\text { Cost of furniture and office } \\
\text { equipment }\end{array}$ & \\
\hline Spaced-related & $2,422,727,855$ \\
\hline Maintenance and repair costs & $* 80,812,523$ \\
\hline $\begin{array}{l}\text { Depreciation costs for non- } \\
\text { functional buildings }\end{array}$ & \\
\hline Service-related & $573,907,565$ \\
\hline Cost of using procurement goods & $1,291,058,615$ \\
\hline Office and subscription fees & $12,688,627,658$ \\
\hline Total &
\end{tabular}

From the total of indirect resource costs nonfunctional unit, the overhead will be charged to each functional unit in accordance with the proportion of its income

Table 5. Income Proportion each unit 2017

\begin{tabular}{lrrr}
\hline \multicolumn{1}{c}{ Unit } & Income (Rp) & (\%) & \multicolumn{1}{c}{$\begin{array}{c}\text { Cost Indirect } \\
\text { Resource } \\
\text { Overhead (Rp) }\end{array}$} \\
\hline Inpatient & 13.382 .887 .000 & $19 \%$ & 2.355 .967 .922 \\
Outpatient & $13,343,467,000$ & $19 \%$ & 2.349 .028 .294 \\
Operation & 9.552 .014 .000 & $13 \%$ & $\mathbf{1 . 6 8 1 . 5 6 8 . 3 0 3}$ \\
Support & 35.798 .364 .674 & $50 \%$ & 6.302 .063 .138 \\
Total & 72.076 .732 .674 & $100 \%$ & 12.688 .627 .658 \\
\hline
\end{tabular}

From the table5, it is known that the indirect resource overhead for the Operation room unit is Rp. 1.681.568,00. To find out the charging fees of each patient in IBS, then it is carried out according to the type of surgery the patient receives, as in the following table

Table 6. Operation in 2017 and impositions factors

\begin{tabular}{lcc}
\hline \multicolumn{1}{c}{ Classification } & Operation & Impositions \\
\hline Small Surgery & 0 & 0.5 \\
Midle Surgery & 271 & 1 \\
Big Surgery & 1,022 & 1.5 \\
Special Surgery & 2,554 & 2
\end{tabular}

Total

3,874

5

According to the Mayor of Yogyakarta Regulation Number 104 of 2009 concerning the tariff for health services at Yogyakarta public hospitals, Sectio Caesarea surgery is included in the category of major surgery. Based on table 5, the imposition of all IBS major operations in Yogyakarta City Hospital is Rp.134.018415,00.* By looking at the number of major operations in 2017 in the Yogyakarta City General Hospital as many as 1022, indirect costs for each large operation are $\mathrm{Rp} 131.133,00^{* *}$. Details of imposition based on the activities carried out or obtained by the patient as follows

Table 7. Impositions Indirect Resource Overhead per patient

\begin{tabular}{|c|c|c|}
\hline Activity Center & $\begin{array}{c}\text { Time } \\
\text { (minute) }\end{array}$ & $\underset{* \ldots *}{\text { Cost (Rp) }}$ \\
\hline \multicolumn{3}{|l|}{ Operating Room (Preoperative) } \\
\hline $\begin{array}{l}\text { Patient admission by IBS officers } \\
\text { from ward nurses }\end{array}$ & 5 & 5,961 \\
\hline Giving antibiotic profilaksis & 25 & 29,803 \\
\hline $500 \mathrm{cc} \mathrm{NaCl}$ infusion liquid & 5 & 5,961 \\
\hline \multicolumn{3}{|l|}{$\begin{array}{l}\text { Operating Room (operating } \\
\text { durante) }\end{array}$} \\
\hline $\begin{array}{l}\text { Examination of vital signs by the } \\
\text { anesthetist }\end{array}$ & 5 & 5,961 \\
\hline $\begin{array}{l}\text { Regional Anesthetic Actions } \\
\text { (Spinal) }\end{array}$ & 10 & 11,921 \\
\hline The action of sectio caesarea & 45 & 53,646 \\
\hline $\begin{array}{l}\text { Check for complications and } \\
\text { bleeding }\end{array}$ & 5 & 5,961 \\
\hline \multicolumn{3}{|l|}{ Post Operation Operating Room } \\
\hline Score by anesthetist & 5 & 5,961 \\
\hline $\begin{array}{l}\text { Handover of patients by IBS } \\
\text { officers to nurses }\end{array}$ & 5 & 5,961 \\
\hline Total & 110 & 131,133 \\
\hline \multicolumn{3}{|c|}{$\begin{array}{l}*\left\{\frac{\text { Major surgery } \times \text { impositisons factor }}{\text { total surgery } \times \text { impositions factor }}\right\} \times \text { Indirect resource overhe } \\
\text { Operation room }\end{array}$} \\
\hline
\end{tabular}

Next step is determine the direct overhead resource operating room.

Direct resource overhead devided into 4 categories: labourrelated, equipment-related, space-related, serviced-related

Table 8. Direct Resource Overhead

\begin{tabular}{lc}
\hline Direct Resource overhead & Cost (Rp) \\
\hline Labour-related & \\
Labour salary & $1,404,531,259$
\end{tabular}


Equipment-related

\begin{tabular}{lr}
\hline \multicolumn{2}{l}{ Table 8. (continued) Direct Resource Overhead } \\
\hline Direct Resource overhead & \multicolumn{1}{c}{ Cost (Rp) } \\
\hline Medical equipment costs & 360,567 \\
Non-Medical equipment costs & $8,757,424$ \\
IBS equipment and building maintenance & $22,545,052$ \\
costs & \\
Space-related & \\
The cost of depreciating & $15,804,257$ \\
Serviced-related & \\
Electricity costs for surgery room & $56,037,132$ \\
water costs for surgery room & $172,009,456$ \\
telephone costs for surgery room & $4,710,888$ \\
Cleaning costs for surgery room & $75,413,712$ \\
\multicolumn{1}{c}{ Total } & $\mathbf{1 , 5 8 8 , 3 3 2 , 3 0 0}$ \\
\hline
\end{tabular}

From table 8 can be seen that the direct overhead resource of the Central Surgical Installation of Yogyakarta City Hospital is Rp. 1,588,332,300.00. These costs will be borne by all patients in the Central Surgery Installation by observing the type of operation performed (according to table 5). According to Mayor's regulation number 104 of 2009 concerning the tariffs for Yogyakarta City Hospital, the Actions of Sectio caesarea fall into the category of major surgery. Then the major surgery operation received a charge of Rp. 126,587,648.30*. In 2017, there are 1022 major surgery, so each operation of major surgery costs $\mathrm{Rp}$ $123.863,00^{* *}$ for direct resource overhead. The details of imposing direct resource overhead costs on activities are in the following table

Table 9. Impositions Direct Resource Overhead per Patient

\begin{tabular}{lcr}
\hline \multicolumn{1}{c}{ Activity Center } & $\begin{array}{c}\text { Time } \\
\text { (minute) }\end{array}$ & $\begin{array}{c}\text { Cost } \\
\text { (Rp) })^{* * *}\end{array}$ \\
\hline $\begin{array}{l}\text { Operating Room (Preoperative) } \\
\text { Patient admission by IBS officers } \\
\text { from ward nurses }\end{array}$ & 5 & 5,630 \\
$\begin{array}{l}\text { Giving antibiotic profilaksis } \\
500 \mathrm{cc} \mathrm{NaCl} \text { infusion liquid }\end{array}$ & 25 & 28,151 \\
$\begin{array}{l}\text { Operating Room (operating } \\
\text { durante) }\end{array}$ & 5 & 5,630 \\
$\begin{array}{l}\text { Examination of vital signs by the } \\
\text { anesthetist }\end{array}$ & 5 & 5,630 \\
$\begin{array}{l}\text { Regional Anesthetic Actions } \\
\text { (Spinal) }\end{array}$ & 10 & 11,260 \\
$\begin{array}{l}\text { The action of sectio caesarea } \\
\text { Check for complications and }\end{array}$ & 45 & 50,671 \\
$\begin{array}{l}\text { bleeding } \\
\text { Post Operation Operating Room }\end{array}$ & 5 & 5,630 \\
$\begin{array}{l}\text { Score by anesthetist } \\
\text { Handover of patients by IBS } \\
\text { officers to nurses }\end{array}$ & 5 & 5,630
\end{tabular}

Total 110
$\begin{aligned} & *\left\{\frac{\text { major surgery } \times \text { impositions factor }}{\text { total surgery } \times \text { impositions factor }}\right\} \times \text { direct } \\ & \text { overhead operating room }\end{aligned}$
$* *$ Rp $126.578 .643,00 / 1022$ (total major surgery)
$* * *($ time/total time) $\times$ total direct resource per patient

From table 9 can be seen each activities in Sectio caesarea operation produce costs in detail according to the time needed. Total costs produce per patient is $\mathrm{Rp} 123.863,00^{* *}$

\section{Charges overhead costs in each activity center}

After knowing the indirect costs and direct resource overhead, the next step is calculate total overhead then impose the activities carried out during the delivery of the caesarea sectio service. The number of activities is calculated, based on the results of observations directly in the operating room on the caesarean sectio surgery without complications in Yogyakarta City Hospital

Table 10. Total Overhead Cost

\begin{tabular}{cccc}
\hline Activity Center & Activit & $\begin{array}{c}\text { Total } \\
\text { Overhead }\end{array}$ & $\begin{array}{c}\text { Cost } \\
\text { (Rp) }\end{array}$ \\
& $y$ & (Rp) & \\
\hline
\end{tabular}

\section{Operating Room \\ (Preoperative)}

Patient admission by IBS

officers from ward nurses

Giving antibiotic

profilaksis

$500 \mathrm{cc} \mathrm{NaCl}$ infusion

liquid

$\begin{array}{lll}1 & 11,591 & 11,591 \\ 1 & 57,594 & 57,594 \\ 1 & 11,591 & 11,591\end{array}$

\section{Operating Room}

(operating durante)

Examination of vital signs

by the anesthetist

Regional Anesthetic

Actions (Spinal)

The action of sectio

caesarea

Check for complications

and bleeding

Post Operation

Operating Room

Score by anesthetist $\quad 1 \quad 11,591 \quad 11,591$

Handover of patients by $\quad 1 \quad 11,591 \quad 11,591$

IBS officers to nurses
Total

From table 10 can be seen summary of indirect overhead resources and direct overhead resources (total indirect resources) applied to how many 
times, an activity in single service. The result is $\mathrm{Rp}$ $266,287.00$

Next step is add overhead cost with dirct cost, so we can find cost of section caesarea services by using activity-based costing.

Add Direct cost and Overhead cost

Table 11. Total cost

\begin{tabular}{lr}
\hline \multicolumn{1}{c}{ Cost structure } & Cost (Rp) \\
\hline Direct Cost & $2,437,332$ \\
Overhead Cost & 266,287 \\
& $2,703,919$ \\
\hline
\end{tabular}

\section{Discussion}

Based on the research that has been done, it is obtained the action rate data sectio caesarea in Yogyakarta City Hospital still uses the traditional method in

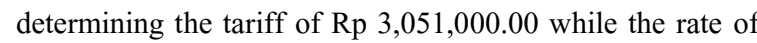
sectio caesarea in Yogyakarta City Hospital uses the Activity based-costing calculation of Rp2.703.919,00the difference between the two rates is Rp347.081,00with rates at larger hospitals

Table 12. Unit cost ABC Method and tariff Yogyakarta City Hospital

\begin{tabular}{lcr}
\hline & ABC (Rp) & $\begin{array}{l}\text { Tarif RSUD Kota } \\
\text { Yogyakarta (Rp) }\end{array}$ \\
\hline Calculation & 2,703919 & $3,051,000$ \\
\hline
\end{tabular}

The initial stage of calculating the unit cost of cesarean sectio without complication in Yogyakarta City Hospital is to determine the activities carried out during the Caesarea sectio. The unit related to the sectio caesarea at the RSUD Kota Yogyakarta is a central surgical installation unit. According to the mayor's regulation number 104 of 2009 regarding the rates of Yogyakarta City Hospital, the sectio caesarea was included in major surgery.

The direct cost in the calculation of the unit cost of the caesarea sectio is Rp. 2,437,332.00 with the details of the largest costs in the cost of doctor services, namely $\mathrm{Rp}$. 1,040,000.00 with details of Rp. 780,000 for obstetricians, and Rp. anesthetist. In addition to doctors' fees, other costs that arise are costs for consumables, namely drugs and ingredients used during surgery. The drugs used in RSUD Kota Yogyakarta are generic drugs and the use of materials in action is tailored to the needs of the patient. Yogyakarta City Hospital itself does not have a package of consumables in one action sectio caesarea. The use of consumables depends on the patient's condition in the operating room.

The next direct cost that arises is the cost incurred for the process of once sterilizing the sectio caesarea tools. RSUD Kota Yogyakarta does not have a fixed rate used for the sterilization process. This is because the sterilization unit of Yogyakarta City Hospital is still relatively new, namely in 2015.

After making direct cost calculations, the next cost that arises is overhead. Overheads are costs that are difficult to be charged directly to patients. Overhead costs are divided into two: indirect feedback and direct resource overhead. ${ }^{12}$ The results of the study show that the highest costs in overhead costs are in the salary of non-functional units. Assessment of employee salary efficiency policies requires further research on workload and job analysis.

The next highest cost of overhead costs lies in the cost of maintenance and repairs. Maintenance and repair costs consist of costs needed for maintenance of buildings / buildings, maintenance of equipment and office supplies, and maintenance costs for cleaning. The three posts require further details to analyze whether efficiency needs to be done or not.

Costs incurred later in overhead costs are related and service-related equipment costs. Yogyakarta City Hospital has just purchased a surgical medical instrument in 2015 so that medical devices used in the caesarean sectio operation still have economic value.

Based on the results of the study with the difference in unit cost obtained, it was concluded that the activity-based costing method has a lower value and is in accordance with the activities carried out. This lower difference needs to be taken into consideration in relation to other units that also support the implementation of caesarean sectio services such as inpatient units so that the management of Yogyakarta City Hospital can conduct a review of the Caesarea sectio action rates whether it is appropriate or not.

Activity-based costing ( $\mathrm{ABC}$ ) is a cost calculation method that changes the way business management is managed. If in the traditional method, the calculation of rates uses a function as its main view, then the $\mathrm{ABC}$ method uses activities as its views. Focusing on calculations for activities is based on the belief that activities are things that cause costs. By looking at activities, it will be able to reduce unnecessary costs and even eliminate costs that have minimal value. The use of this method will make changes in the form of changes in orientation from cost management to focus on value through cost effective. The $\mathrm{ABC}$ method will also create integration between functions aimed at 
value. $\frac{19}{}$ Changes achieved by the use of the $\mathrm{ABC}$ method are believed to be more accurate in calculating costs.

\section{CONCLUSION}

From the results of this study the following conclusions are obtained that unit cost of caesarean sectio without complications in Yogyakarta City Hospital using Activitybased costing method is Rp2,703,919.00. There is a difference in unit cost between the $\mathrm{ABC}$ method and the rate that has been determined by the Yogyakarta City General Hospital of Rp347,081.00 with the lower ABC method. Suggestion are: Calculation of unit costs using Activity-based costing method can be a consideration for management in determining rates by paying attention to other units involved such as inpatient units in the framework of evaluation, BPJS era requires hospitals to be careful in calculating rates. BPJS will only pay according to the amount of the predetermined claim. by knowing the unit cost of sectio caesarea in the operating room, it will make it easier for hospitals to estimate existing costs in the area in order to do a complete service..

Make a package of consumables for sectio caesarea: At the time of the study, the researchers saw no minimum package for consumables used for patients with sectio cesarean without complications. During the process the procedure for sectio caesarea is very dynamic for the needs requested. Sometimes it can be more expensive, sometimes it can be cheaper according to the patient's condition. it will be more efficient if there is already a package of consumables, in order to be able to control the use of existing items.

Making clinical pathway actions sectio caesarea in Yogyakarta City Hospital: At the time of the research, RSUD Kota Yogyakarta did not have a clinical pathway in writing, among doctors the obsgyn adhered to the agreed upon procedures.

\section{REFERENCE}

1. Presiden RI. Undang-undang Republik Indonesia No. 40 Tahun 2004 tentang Sistem Jaminan Sosial Nasional-[PERATURAN]. 2004;

2. BPJS K. InfoBPJS. BPJS Kesehatan; 2016.

3. WHO. Universal Health Coverage: Supporting Country Needs. 2017.

4. Melnick GA, Zwanziger J, Bamezai A, Pattison R. The effects of market structure and bargaining position on hospital prices. journal of Health Economics. 1992;11(3):217-233.
5. Prawirohardjo S. Ilmu Bedah Kebidanan. I. Yayasan Bina Pustaka Sarwono Prawirohardjo; 2000. (3).

6. Liweru MD, Lengkong VP, Kaunang Wp. Analisis Kelayakan Penggunaan Tarif Sectio Caesarea Berdasarkan Relative Value Unit Di Bagian Obstetri Dan Ginekologi Rsup Prof. Dr. Rd Kandou Manado Tahun 2015. ikmas. 2017;2(5)

7. Javid M, Hadian M, Ghaderi H, Ghaffari S, Salehi M. Application of the Activity-Based Costing Method for Unit-Cost Calculation in a Hospital. Global Journal of Health Science. 2015 May 17;8(1):165.

8. Honsen, Mowen. Managerial accounting (akutansi biaya). Salemba Empat, Jakarta. 2009;1.

9. Setiaji H. Analisis Biaya Pelayanan Rawat Inap Di Ruang Vip Cendrawasih Rsud Dr. Soeselo Kabupaten Tegal Tahun 2006 [PhD Thesis]. Program Pascasarjana Universitas Diponegoro; 2008.

10. Posner RA. Cost-Benefit Analysis: Definition, Justification, and Comment on Conference Papers. The Journal of Legal Studies. 2000 Jun;29(S2):1153-77.

11. Nowicki M. The Financial Management of Hospital and Healthcare Organizations. 4th ed. United States of America: Health Administration Press; 2008.

12. Baker J. Activity--based Costing and Activity-Based Management for Health Care. United States: Aspen Publisher; 1998.

13. Demeere N, Stouthuysen K, Roodhooft F. Time-driven activity-based costing in an outpatient clinic environment: development, relevance and managerial impact. Health policy. 2009;92(2):296-304.

14. Grandlich C. Using activity-based costing in surgery. AORN J. 2004 Jan;79(1):189-92.

15. Rahma AY. Analisis Unit Cost Tindakan Operasi Appendiktomi dengan Metode Activity Based Costing di RS PKU Muhammadiyah Bantul. 2015.

16. Bayati M, Ahari AM, Badakhshan A, Gholipour M, Joulaei H. Cost Analysis of MRI Services in Iran: An Application of Activity Based Costing Technique. Iranian Journal of Radiology. 2015;12(4).

17. Lexa FJ, Mehta T, Seidmann A. Managerial accounting applications in radiology. Journal of the American College of Radiology. 2005 Mar;2(3):262-70.

18. Kumar A. Towards the use of ontologies for activitybased costing in healthcare organizations. Stud Health Technol Inform. 2006;124:537-42.

19. Mulyadi. Activity-based costing system, sistem informasi biaya untuk pemberdayaan karyawan, pengurangan biaya, dan penentuan secara akurat kos produk dan jasa. Yogyakarta: UPP STIM YKPN; 2007. 